\title{
Correlation Between Preoperative Vein Distensibility With Radiocephalic Arteriovenous Fistula Maturation in Patients With End Stage Renal Disease Putie Hapsari, ${ }^{1 *}$ Teguh Marfen Djajakusumah, ${ }^{1}$ Zacky Fauzie, ${ }^{1}$ Muhammad Faiz Ulurrosyad ${ }^{1}$
}

Introduction: Patients with end stage renal disease require hemodialysis. Radiocephalic arteriovenous fistula is the main choice of vascular access in patients who undergo hemodialysis procedure. Physiological vein distensibility is an important aspect in forming a mature arteriovenous fistula. This study aims to analyze the correlation between preoperative distensibility and arteriovenous fistula maturation.

Method: Data are collected from end stage renal disease patients in Hasan Sadikin Hospital and RA Habibie Hospitals that will go through radiocephalic arteriovenous fistula procedure during the period of October 2018 to February 2019. Vein distension procedure is performed before the operation and maturation is evaluated four to six weeks after the operation. The comparison of preoperative venous distensibility in two different groups of arteriovenous fistula maturation category is analyzed using chi square test model.

Result: This study found that preoperative venous distensibility value affects arteriovenous fistula maturation with a statistical significance ( $p$-value $=0.007)$, yielding a contingency coefficient of 0.553 , and a very strong relation value of 0.782 .

Conclusion: Preoperative vein distensibility of more than $30 \%$ is predictive of successful arteriovenous maturation.

Keywords: Venous distensibility, AV fistula, predictor https://doi.org/10.36864/jinasvs.2021.1.003

${ }^{*}$ Correspondence: putie.hapsari@yahoo.com,+6285793347858

${ }^{1}$ M.D., Vascular and Endovascular Division, Department of Surgery, Dr. Hasan Sadikin Hospital - Faculty of Medicine, Universitas Padjadjaran, Bandung, Indonesia

\section{INTRODUCTION}

End stage renal disease (ESRD) patients require kidney replacement therapy to accommodate their renal function. The most commonly used therapy is hemodialysis procedure which requires an arteriovenous (AV) fistula as a vascular access. ${ }^{1}$ Radiocephalic and brachiocephalic AV fistulae are the most preferred accesses due to the better patency and lower risk of complication compared to other vascular accesses. ${ }^{2,3}$

According to Kidney Disease Outcome Quality Initiative (KDOQI), there are three criteria of a mature AV fistula that must be fulfilled, which are a minimum blood flow of $600 \mathrm{~mL} /$ minute, a venous diameter of at least $6 \mathrm{~mm}$, and a distance of at least $6 \mathrm{~mm}$ from the skin surface. It is also agreed that the fistula requires four to six weeks to reach maturation and be utilised for hemodialysis. ${ }^{4-9}$

The failure rate of AV fistula according to previous studies in Europe and Indonesia is still above $30 \% .^{2,10}$ This result suggests that further investigation and identification of factors affecting $A V$ fistula are imperative. The most important factor that determines maturation is the venous physiological profile. ${ }^{11}$ One of the physiological ability of the vein is its distensibility. The vein will respond to an AV fistula by expanding its diameter to increase blood flow. This ability to distend is suggested to predict the maturation of the fistula.11-14 Previous literature conducted in Europe noted that all patients with a vein distensibility of $0,5 \mathrm{~mL} / \mathrm{mmHg}$ or less didn't achieve fistula maturation. Meanwhile, only $20 \%$ of the fistulae in patients with a vein distensibility of more than $0,5 \mathrm{~mL} / \mathrm{mmHg}$ fail. ${ }^{11}$

Considering anatomical differences of European and Asian people, this study aims to analyze the correlation between preoperative distensibility and arteriovenous fistula maturation in Indonesia.

\section{METHOD}

This study is a prospective cohort analytical study. Data are collected from ESRD patients that will undergo radiocephalic AV fistula procedure in Hasan Sadikin Hospital and RA Habibie Hospital during the period of October 2018 - February 2019. Subjects that are included in this study are ESRD patients without venous fibrosis, venous thrombosis, and ipsilateral double-lumen catheter access.

Before undergoing radiocephalic AV fistula procedure, the subject's venous diameter is evaluated using doppler ultrasound. Tourniquet is applied and inflated up to $65 \mathrm{mmHg}$ for one to two minutes. The 
Table 1. Subjects' Characteristics

\begin{tabular}{|c|c|}
\hline Characteristics & $n=20$ \\
\hline \multicolumn{2}{|l|}{ Gender } \\
\hline Male & $9(45 \%)$ \\
\hline Female & $11(55 \%)$ \\
\hline \multicolumn{2}{|l|}{ Age } \\
\hline Mean & 43.15 \\
\hline Range & $24-68$ \\
\hline \multicolumn{2}{|l|}{ Accompanying disease } \\
\hline Hypertension & $19(95 \%)$ \\
\hline Diabetes Mellitus & $0(0 \%)$ \\
\hline Arterial Disease & $0(0 \%)$ \\
\hline Smoking & $8(40 \%)$ \\
\hline \multicolumn{2}{|c|}{ Preoperative venous diameter } \\
\hline Mean & $2.46( \pm 0.43)$ \\
\hline Range & $2.0-3.5$ \\
\hline \multicolumn{2}{|l|}{ Distensibility } \\
\hline Mean & $33.45 \%( \pm 2.16)$ \\
\hline Range & $13 \%-54 \%$ \\
\hline \multicolumn{2}{|l|}{ AV fistula maturity } \\
\hline Mature & $14(70 \%)$ \\
\hline Immature & $6(30 \%)$ \\
\hline
\end{tabular}

difference of the venous diameter before and after tourniquet inflation is calculated.

After radiocephalic AV fistula procedure is done, the patient is evaluated again after four to six weeks. Blood flow, diameter, and depth are evaluated to determine maturation of the fistula.

Characteristics of the patients are observed and the correlation between the maturity of the fistula and vein distensibility is analyzed using chi-square analytical test. The strength of the relation ( $R$ ) is then determined by comparing the contingency coefficient (C) with the $\mathrm{C}$ maximum.

\section{RESULTS}

We found 20 subject that fulfilled the criteria with a distribution as displayed in table 1 . The mean vein distensibility of the sample is $33.45 \%$ with an average preoperative venous diameter of $2.46 \mathrm{~mm}$. fourteen subjects (70\%) achieved maturation four to six weeks after AV fistula procedure meanwhile six subjects $(30 \%)$ did not.

Before proceeding to the analytical test, it is necessary to determine the cut-off point of the subjects' vein distensibility using the receiver operator characteristic (ROC) curve. It is established that the cut-off point in this study is $30 \%$. See Figure 1.

There are 13 subjects ( $65 \%$ ) that have a vein distensibility of more than $30 \%$. Twelve of which $(92.3 \%)$ achieved maturity while only one subject $(7.7 \%)$ did not. Meanwhile, seven subjects (35\%) have less than $30 \%$ vein distensibility in which only two subjects $(28.6 \%)$ achieved maturity and 5 subjects $(71.4 \%)$ did not. See table 2 .
Using the cut-off point, we can now analyze the data using chi-square analytical test. We found a $p$-value of 0.007 and a $C$ value of 0.553 signifying a relation between AV fistula maturation and vein distensibility. The relation strength yields a value of 0.782 (very strong).

\section{DISCUSSION}

Analytical test performed in this study resulted in a cut-off point of $30 \%$. The group of subject with vein distensibility of more than $30 \%$ have a higher rate of fulfilling the KDOQI criteria of AV fistula maturity compared to the group with less than $30 \%$ vein distensibility. The statistical relation between vein distensibility and AV fistula maturity is also very strong. This result is in accordance to previous studies noting that venous profiles, especially distensibility, are important aspects that correlate with AV fistula maturity. ${ }^{11,12}$ Failure of maturity in one sample in the first group may be associated with suboptimal care and nursing of the fistula during the period of maturation, such as trauma and excessive arm activity.

Compared to the study by Linden et al. in Europe that subjects who achieved AV fistula maturity have an average distensibility of $48 \%$, we found that the average vein distensibility in the group with higher maturity rate in our sample is $37.7 \% .{ }^{11}$ The difference in the mean value may be a result of different factors affecting venous physiology. Accompanying diseases that are poorly controlled may also play a role, although the relation was not evaluated in this study. ${ }^{14,15}$

In this study, four subjects $(20 \%)$ did not achieve maturation due inadequate venous dilatation, one subject $(10 \%)$ failed to achieve maturation because of thrombosis formation, and one subject $(10 \%)$ did not achieve maturation due to inadequate depth. Failure rate in this study is in accordance with previous literatures stating that failure rate is above $30 \%, 10,12$

We found that there is a difference in initial venous diameter in European and Indonesia people. ${ }^{15}$ Regardless of this data, maturity and failure rates do not differ significantly between this study and previous ones. We may infer that initial diameter is not an important factor in determining AV fistula maturation compared to distensibility. ${ }^{12}$

Considering the fact that there are anatomical differences between European and Asian people, it is also worth investigating whether or not physiological differences exist. Understanding variations in physiology may prove to be fruitful in predicting AV fistula maturation. ${ }^{15}$.

\section{CONCLUSION}

In conclusion, there is a strong correlation between preoperative vein distensibility and

Table 2. Proportion of vein distensibility with AV fistula maturity

\begin{tabular}{cccc}
\hline $\begin{array}{c}\text { Preoperative vein } \\
\text { distensibility }\end{array}$ & Mature & Immature & Total \\
\cline { 2 - 3 } $\begin{array}{c}\text { Distensibilitas vena } \\
\text { preoperatif }>30 \%\end{array}$ & 12 & 1 & $13(65 \%)$ \\
$\begin{array}{c}\text { Distensibilitas vena } \\
\text { preoperatif }<30 \%\end{array}$ & 2 & 5 & $7(35 \%)$ \\
Total & $14(70 \%)$ & $6(30 \%)$ & $20(100 \%)$ \\
\hline
\end{tabular}




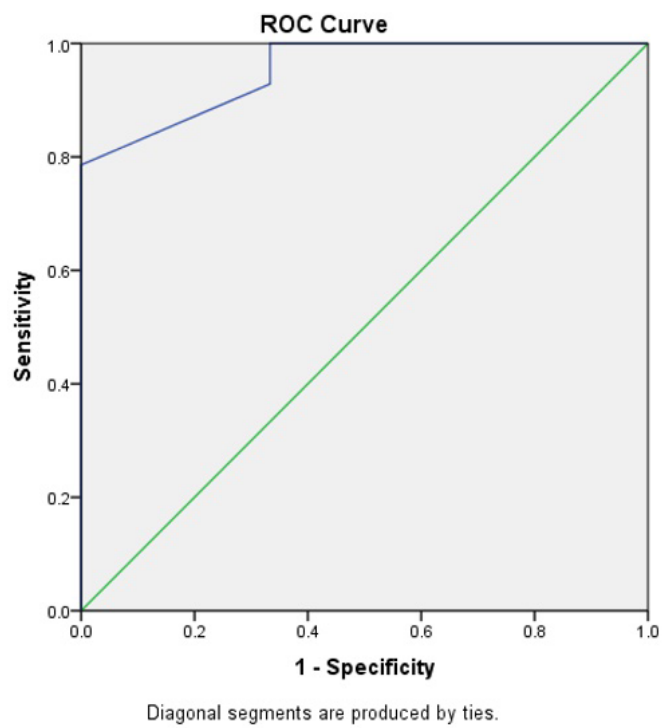

Figure 1. Subjects' vein distensibility using the receiver operator characteristic (ROC) curve radiocephalic AV fistula maturation in ESRD patients. Veins that are able to distend more than $30 \%$ have a higher chance of achieving maturity.

\section{CONFLICT OF INTEREST}

The author states the original work, and there is no conflict of interest in doing this research.

\section{ORCID ID OF AUTHORS}

Putie Hapsari

https://orcid.org/0000-0002-9310-4524

Teguh Marfen Djajakusumah

https://orcid.org/0000-0001-6114-2406

Zacky Fauzie

https://orcid.org/0000-0002-3535-4998

Muhammad Faiz Ulurrosyad

https://orcid.org/0000-0002-0098-4092

\section{REFERENCES}

1. Registry TIR. Situasi Penyakit Ginjal Kronis. In: RI KK, editor. Indonesia: Infodatin, Pusat Data dan Informasi Kementrian Kesehatan RI. 2017.

2. Wilson SE. Patient assessment and planning for vascular access surgery. In: Vascular Access: Principles and practice. $5^{\text {th }}$ ed. Philadelphia. Lippincott William \& Wilkins. Inc. 2010.

3. Lok CE, Huber TS, Lee T, et al. KDOQI Vascular Access Guideline Work Group. KDOQI clinical practice guideline for vascular access: 2019 update. Am J Kidney Dis. 2020;75(4)(suppl 2):S1-S16.

4. Navuluri R, Regalado S. The KDOQI 2006 Vascular Access Update and Fistula First Program Synopsis. Semin Intervent Radiol. 2009Jun;26(2):122-4.

5. Padberg FT Jr, Calligaro KD, Sidawy AN. Complications of arteriovenous hemodialysis access: recognition and management. J Vasc Surg. 2008Nov;48(5 Suppl):55S-80S.

6. Sidawy AN, Gray R, Besarab A, et al. Recommended standards for reports dealing with arteriovenous hemodialysis accesses. J Vasc Surg. 2002Mar;35(3):603-10.

7. Berman S. Vascular Access in Clinical Practice. Arizona. Marcel Dekker, Inc. 2002.

8. Yuwono H. Operasi Cimino. Ilmu Bedah Vaskular Sains dan Pengalaman Praktis. 1 ed. Indonesia. Refika Aditama. 2010;67-98.

9. Khavanin MZ, Mohammadipour S, Omrani Z. Correlation between CRP and early failure of arteriovenous fistula (AVF). Med J Islam Repub Iran. 2015Jun8;29:219.

10. Cliff WS, Limpeleh H, Monoarfa A. Persentase keberhasilan operasi Cimino dan AV-Shunt cubiti pada pasien hemodialisa di RSUP Prof Kandou periode Januari 2013-Desember 2013. Journal E-Clinic. 2013;38.

11. van der Linden J, Lameris TW, van den Meiracker AH, et al. Forearm venous distensibility predicts successful arteriovenous fistula. Am J Kidney Dis. 2006Jun;47(6):1013-9.

12. Roy-Chaudhury P, Spergel LM, Besarab A, Asif A, Ravani P. Biology of arteriovenous fistula failure. J Nephrol. 2007Mar-Apr;20(2):150-63.

13. Guzman RJ, Abe K, Zarins CK. Flow-induced arterial enlargement is inhibited by suppression of nitric oxide synthase activity in vivo. Surgery. 1997Aug;122(2):273-9.

14. Keren G. Compensatory Enlargement, Remodeling, and Restenosis. Analytical and Quantitative Cardiology. Boston, MA. Springer US. 1997;187-96.

15. Lauvao LS, Ihnat DM, Goshima KR, Chavez L, Gruessner AC, Mills JL Sr. Vein diameter is the major predictor of fistula maturation. J Vasc Surg. 2009Jun;49(6):1499-504 